\title{
Developing Instrument Assessment of Student's Process Skills in Physics Learning Based on Local Wisdom
}

\author{
Allivna ${ }^{1}$, Mundilarto $^{2}$
}

\section{ARTICLE INFO}

\section{Article History:}

Received 03.01.2019

Received in revised form

14.05.2019

Accepted

Available online 01.10.2019

\begin{abstract}
The aim of this research is to produce instrument of student process skill assessment on project learning based on local wisdom gasing bamboo. The process skill assessment instrument is an observation sheet. The method used in this study refers to Mardapi development. The research step is to arrange instrument specification, write manuscript, study instrument, instrument test, instrument analysis and instrument revision. The instrument is validated by 10 validators for analysis through Aiken V and uses eduG-6e to calculate its reliability. The conclusion in this research is generated instrument of assessment process with its validity range between 0,73 until 1.00 and its reliability value equal to 1.00 .
\end{abstract}

(C) IJERE. All rights reserved

Keywords: ${ }^{1}$

Assesment instrument, local wisdom, project physics learning

\section{INTRODUCTION}

Currently local wisdom began to be forgotten and replaced by technological advances very rapidly. In fact, local wisdom is a local cultural value that can be utilized to regulate the life of society wisely (Mungmachon, 2012). The lack of integration of local wisdom in learning leads to less contextual and meaningful learning (Pornpimon, C., Wallapha, A., \& Prayuth, C , 2014). This is due to a lack of understanding of teachers in utilizing the environment as a medium and a source for the learning process, especially physics (Okland, G. M, 2012; Brooks, Sara., Dobbins, Kerry., Scott, J.A.,2014). Students become less concerned about the local wisdom they have. Local wisdom that has not been much integrated in learning can make learning less contextual and less meaningful, so that learners are less concerned about it (Kanhadilok, P., \& Watts, M. Western, 2013). Learning has a function or role to inherit the culture of the nation to the younger generation so that the culture $\mathrm{w}$ ill be sustainable and can be passed on to the next generation (Ardiansyah,R., Suharno, Triyanto, 2018). Therefore, a local wisdom-based learning is required. Application of local wisdom in learning can stimulate students' sensitivity. Students can apply science, especially physics into the local culture possessed by their environment (Bowker, R., \& Tearle, P, 2007). The local wisdom applied in the study of physics must have characteristics corresponding to the material of physics (Suastra, I. W. \& Yasmini, L. P. B., 2013). The suitability of these characteristics facilitates the achievement of physics learning objectives. Indonesian traditional games are very diverse (Cahyono, N., 2011). Traditional games like gasing, yoyo, catapults can be made easily. The form of learning can be through games (games), simulations, field work (field work), and projects [(Mungmachon, 2012). The number of types and ease in making this makes local wisdom like the manufacture of gas can be applied in the learning of physics. Project learning focuses on the student process in building concepts, basic principles of materials and process skills through investigation, solving real problems and making carefully designed works (Gulay, B., 2015; Hosnan, 2014). Project learning can train students' process skills (Ergül, N. R., \& Keskin, E., 2014; Kettanun, C.,2015; Lasauskiene, J., \& Rauduvaite, A., 2015; Zouganeli, E., Tyssø, V., Feng, B., Arnesen, K., \& Kapetanovic, N., 2014). Process skills can be measured through observation (Feyzioğlu, B., Demirdağ, B., Aky1ldız, M., \& Altun, E., 2012). Based on the description, it is necessary to do the learning based on local wisdom gasing through the project to measure the student's process skill.

\section{Situation of the Problem}

Learning and assessment cannot be separated. The purpose of the assessment is to monitor and evaluate the process, learning progress and improvement of learning outcomes on an ongoing basis. However, current assessments have not been made in accordance with the terms and standards (Subali, B.,

Corresponding e-mail: allivna2012@gmail.com ${ }^{1}$, mundilarto@uny.ac.id ${ }^{2}$

1; hhtpp:///orcid.org/0000-0001-6436-6448

Yogyakarta State University ${ }^{1}$, Yogyakarta State University ${ }^{2}$ 
2010). Most teachers focus more on cognitive assessment at the end of learning (Kulkarni, B.D., \& Tendolkar, V.D., 2015; Saputra, D.I., Abdullah, A.G., \& Hakim, D.L, 2014; Osadebe, U., 2014). The learning difficulties of students become undetectable quickly. Required assessment instruments to measure process skill. Previous research, produced syntax of outdoor learning model through local wisdom-based project in physics learning. Materials developed about circular motion (Damayanti, Indah Kurnia P., 2017). The assessment instrument has not been the main focus of prior research. Therefore, a study entitled the development of a process skill assessment instrument on project-based learning of local wisdom gasing needs to be done.

\section{Aim of the Study}

This research develops a valid and reliable instrument of students' process skill assessment. Instrument validity based on Aiken $\mathrm{V}$ coefficient analysis, while reliability is based on the G relative coefficient which is the edu_G program analyzes. Assessment instruments are used to measure students' process skills in participating in learning local wisdom-based projects, gasing bamboo from Central Java-Indonesia. Assessment instruments are in the form of observation sheets and assessment grids. The material of rotational dynamics and equilibrium of rigid bodies is integrated in bamboo gasing..

\section{METHOD}

This research method is an instrument development model developed by Mardapi (Mardapi, D., 2012). The model is presented in figure 1.

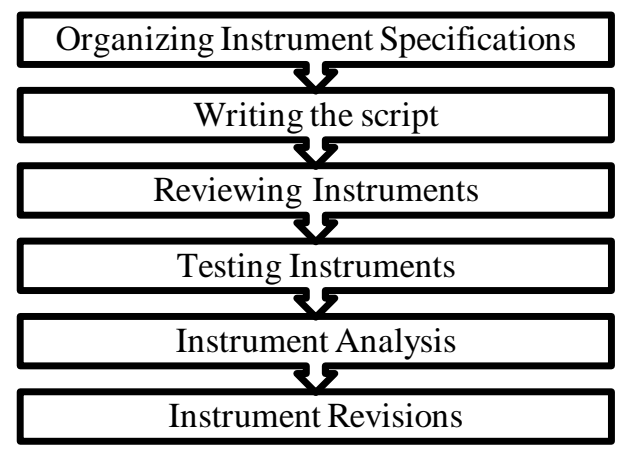

Figure 1. Research Method

In organizing instrument specification phase, the process skill assessment instrument consists of 7 aspects of process skills, each of which is described by several indicators. The number of assessment indicators is 19 which are stated in the statement on the grid of the assessment. And then, writing the script is doing by scriptwriting based on the grading grid. The scoring text is an observation sheet containing the assessment statement. Each of these statements has 4 score criteria. Instrument is reviewed by validators. The validity test involves 10 validators. The validation result is in the form of criticism and suggestion and score of each item. Criticism and suggestion use to the revision guidelines. The validator scores were analyzed to determine the validity of the instrument. The last, the instrument was piloted on 5 of 36 high school students of Muhammadiyah Muntilan 1 on testing phase. This activity involves 5 raters. 36 students undertook project studies based on local wisdom gasing. Scores of assessment results were analyzed to determine the value of the instrument's reliability.

\section{Material}

The instrument used to collect data is in the form of grids, rubrics and process skill observation sheets. Instrument data is validation scores which which are analyzed for validity using the Aiken $\mathrm{V}$ coeficient. Test data is student scores which are tested limited for reliability. The reliability analyse use the edu_G program.

\section{Data Analyses}

The analysis includes validity test and instrument reliability. Validity test was performed using Aiken $V$ analysis. Reliability test using eduG-6e. To calculate Aiken's $V$ index using formula 1.

$$
V=\frac{\sum s}{(n(c-1))}
$$


$V$ is Aiken's $\mathrm{V}$ index, $\sum s$ is the number s of $\mathrm{n}$ raters, $s=r-l_{0}, \mathrm{r}$ is the score given by rater, $l_{0}$ is the lowest validity score, $c$ is the highest validity score. The minimum limit of Aiken's $V$ Index for the instrument is said to be valid in accordance with the Table of validity coefficients of the item, which is $\geq 0.73$ with 10 validators (R, Aiken, 1985). EduG is a program developed based on Analysis of Variance (ANOVA) and Generalizability Theory (Hadi, S.,2018). G Theory is a "grand theory" of the dependability or reliability of behavioral measurement (Cardinet, Jean, Sandra Johnson, Gianreto Pini, 2010). The item is said to be reliable if the reliability value is more than 0.85 (Retnawati, 2016: 86). Instrument revision is done based on test result of validity and reliability.

\section{FINDINGS}

The specification of the process skills assessment instrument is presented in the form of a grading grid. This initial instrument consists of 19 items, which shows by Table 1 .

Table 1. The grid Assessment of Process Skills

\begin{tabular}{|c|c|c|c|c|}
\hline & Aspect & Item Indicator & Statement & Item Code \\
\hline \multirow[t]{3}{*}{1.} & Observing & Delivering observations & $\begin{array}{l}\text { Student's skill in delivering observation } \\
\text { result. }\end{array}$ & $1 \mathrm{a}$ \\
\hline & & b. Collecting reference & $\begin{array}{l}\text { The student's ability to collect references } \\
\text { in learning }\end{array}$ & $1 b$ \\
\hline & & $\begin{array}{l}\text { c. Observing with sensory } \\
\text { devices }\end{array}$ & $\begin{array}{l}\text { Student skills to use the sense apparatus } \\
\text { in learning. }\end{array}$ & 1c \\
\hline \multirow[t]{2}{*}{2.} & Measuring & $\begin{array}{l}\text { a. Using tools during } \\
\text { project learning }\end{array}$ & $\begin{array}{l}\text { The accuracy of students in operating } \\
\text { measuring tools }\end{array}$ & $2 a$ \\
\hline & & $\begin{array}{l}\text { b. Using a tool during an } \\
\text { experiment. }\end{array}$ & $\begin{array}{l}\text { The accuracy of students in operating the } \\
\text { measuring tools. }\end{array}$ & $2 b$ \\
\hline \multirow[t]{3}{*}{3.} & Experiment & $\begin{array}{l}\text { a. Preparing for } \\
\text { experiment }\end{array}$ & $\begin{array}{l}\text { Readiness of students in conducting } \\
\text { experiments }\end{array}$ & $3 a$ \\
\hline & & b. Designing product & Students skills in designing products & $3 b$ \\
\hline & & $\begin{array}{l}\text { c. Experiment } \\
\text { implementation. }\end{array}$ & $\begin{array}{l}\text { The ability of students to carry out the } \\
\text { work steps according to project } \\
\text { procedures. }\end{array}$ & $3 c$ \\
\hline \multirow[t]{2}{*}{4.} & Inference & $\begin{array}{l}\text { a. Using data information } \\
\text { in arranging inference }\end{array}$ & $\begin{array}{l}\text { Ability to use data information in } \\
\text { arranging inference. }\end{array}$ & $4 a$ \\
\hline & & $\begin{array}{l}\text { b. Collecting data } \\
\text { information }\end{array}$ & Ability to use data information. & $4 b$ \\
\hline \multirow[t]{3}{*}{5.} & Predict & $\begin{array}{l}\text { a. Developing } \\
\text { experimental } \\
\text { hypotheses }\end{array}$ & $\begin{array}{l}\text { The ability of students in preparing } \\
\text { experimental hypotheses. }\end{array}$ & $5 a$ \\
\hline & & b. Identifying variables & $\begin{array}{l}\text { Students' ability to identify experiment } \\
\text { variables }\end{array}$ & $5 b$ \\
\hline & & $\begin{array}{l}\text { c. Identify relationships } \\
\text { between variables }\end{array}$ & $\begin{array}{l}\text { Students' ability to identify variable } \\
\text { relations. }\end{array}$ & $5 c$ \\
\hline \multirow[t]{3}{*}{6.} & $\begin{array}{l}\text { Comunicati } \\
\text { ons }\end{array}$ & $\begin{array}{l}\text { a. Submission of } \\
\text { observation results }\end{array}$ & $\begin{array}{l}\text { Skills of students in delivering } \\
\text { observations }\end{array}$ & $6 a$ \\
\hline & & b. Presenting the product & $\begin{array}{l}\text { The ability of students in presenting the } \\
\text { product. }\end{array}$ & $6 b$ \\
\hline & & c. Grouping discussion & Students' ability to discuss in groups. & $6 c$ \\
\hline \multirow[t]{3}{*}{7.} & $\begin{array}{l}\text { Giving } \\
\text { Conclusion }\end{array}$ & $\begin{array}{l}\text { a. Developing ideas to } \\
\text { explain the observations }\end{array}$ & $\begin{array}{l}\text { Students' ability to devise ideas to explain } \\
\text { observations }\end{array}$ & $7 a$ \\
\hline & & $\begin{array}{l}\text { b. Stating a fact-based } \\
\text { conclusion. }\end{array}$ & $\begin{array}{l}\text { Ability of students to conclude based on } \\
\text { facts. }\end{array}$ & $7 \mathrm{~b}$ \\
\hline & & $\begin{array}{l}\text { c. Expressing the } \\
\text { conclusions during the }\end{array}$ & $\begin{array}{l}\text { The ability of students to conclude the } \\
\text { discussion. }\end{array}$ & $7 \mathrm{c}$ \\
\hline
\end{tabular}




\begin{tabular}{|c|c|c|c|}
\hline Aspect & Item Indicator & Statement & Item Code \\
\hline & ussion & & \\
\hline
\end{tabular}

Each assessment statement is integrated into 4 categories of scores on observation sheet. One form of assessment show by Table 2 .

Table 2. Rubric Assessment of Process Skills

\begin{tabular}{|c|c|c|c|}
\hline Item Code & Statement & Criteria & Score \\
\hline 1a & $\begin{array}{l}\text { Student's skill in } \\
\text { delivering } \\
\text { observation result. }\end{array}$ & $\begin{array}{l}\text { 1. Convey the observation result to the student group. } \\
\text { 2. Delivering observations to other groups orally } \\
\text { (presentation). } \\
\text { 3. Delivering the results of observation in writing. } \\
\text { 4. Delivering observations clearly. }\end{array}$ & \\
\hline
\end{tabular}

Rater writes a score based on the number of criteria met. A score 1 for 1 criterion accepted, a score of 2 to 2 criteria accepted and so on.

Instrument is then validated by 10 validators. Validation analysis shows that 16 of 19 items are valid, while 3 items are declared invalid. Details of content validation analysis show by Table 3.

Table 3. Results of Instrument Validation Item Analysis

\begin{tabular}{cccc}
\hline Item Code & Aiken V & Decision & Information \\
\hline $1 \mathrm{~b}$ & 1.00 & valid & No revision \\
$1 \mathrm{c}$ & 0.93 & valid & Revision \\
$\mathrm{2a}$ & 0.93 & valid & Revision \\
$\mathrm{2b}$ & 0.93 & valid & Revision \\
$\mathrm{3a}$ & 0.73 & valid & Revision \\
$3 \mathrm{~b}$ & 1.00 & valid & No revision \\
$\mathrm{3c}$ & 0.99 & valid & No revision \\
$4 \mathrm{a}$ & 0.93 & valid & Revision \\
$4 \mathrm{~b}$ & 0.97 & valid & No revision \\
$5 \mathrm{a}$ & 0.87 & valid & Revision \\
$5 \mathrm{~b}$ & 0.93 & valid & Revision \\
$5 \mathrm{c}$ & 0.70 & invalid & - \\
$6 \mathrm{a}$ & 1.00 & valid & No revision \\
$6 \mathrm{~b}$ & 0.99 & valid & No revision \\
$6 \mathrm{c}$ & 0.60 & invalid & - \\
$7 \mathrm{a}$ & 0.77 & valid & Revision \\
$7 \mathrm{~b}$ & 1.00 & valid & No revision \\
$7 \mathrm{c}$ & 0.67 & invalid & - \\
\hline
\end{tabular}

There are some valid items revised or without revisions. 7 items are valid without revision and 9 items are revisions based on validator records. Items which need to be revised are show by Table 4 .

Table 4. Validator Suggestions

\begin{tabular}{|c|c|}
\hline Item Code & Revision \\
\hline $1 \mathrm{a}$ & Among the scoring criteria clarified, there are spelling errors on the criteria. \\
\hline $1 c$ & Among the scoring criteria clarified \\
\hline $2 a$ & Criteria adapted to learning activities. \\
\hline $2 b$ & There are spelling errors on the criteria. \\
\hline $3 a$ & $\begin{array}{l}\text { There are spelling errors on the criteria, aspects of the statement are tailored to the } \\
\text { criteria }\end{array}$ \\
\hline
\end{tabular}




\begin{tabular}{cl}
\hline Item Code & \multicolumn{1}{c}{ Revision } \\
\hline $4 \mathrm{a}$ & there are spelling errors on the criteria, \\
$5 \mathrm{a}$ & aspects of the statement are tailored to the criteria \\
$5 \mathrm{~b}$ & There are similarity criteria on point 1 and 3 \\
$5 \mathrm{c}$ & $\begin{array}{l}\text { Aspects, indicators and assessment criteria are less appropriate, among } \\
\text { assessment criteria is clarified. }\end{array}$ \\
$6 \mathrm{c}$ & Aspects, indicators and assessment criteria are not appropriate \\
$7 \mathrm{a}$ & there are spelling errors on the criteria, \\
$7 \mathrm{c}$ & Aspects, indicators, assessment criteria and lesson activities are less appropriate. \\
\hline
\end{tabular}

After the revision, instrument was tested limited. A limited trial was conducted on 5 of 36 students of grade X SMA 1 Muhammadiyah Muntilan, Jawa Tengah. 5 raters assessed 5 students in one group during project learning based on local wisdom gasing.

Table 5. Results of Instrument Reliabilty Analysis

\begin{tabular}{|c|c|c|c|c|c|c|}
\hline $\begin{array}{c}\text { Source of } \\
\text { variance }\end{array}$ & $\begin{array}{l}\text { Differentiation } \\
\text { variance }\end{array}$ & $\begin{array}{l}\text { Source of } \\
\text { variance }\end{array}$ & $\begin{array}{l}\text { Relative error } \\
\text { variance }\end{array}$ & $\%$ relative & $\begin{array}{l}\text { Absolute error } \\
\text { variance }\end{array}$ & $\%$ absolute \\
\hline \multirow[t]{5}{*}{$S$} & 0.04192 & & $\ldots$. & & $\ldots .$. & \\
\hline & $\ldots .$. & B & ..... & & $(0.00000)$ & 0.0 \\
\hline & $\ldots .$. & $\mathrm{R}: \mathrm{B}$ & $\ldots$. & & $(0.00000)$ & 0.0 \\
\hline & ...... & SB & $(0.00000)$ & 0.0 & $(0.00000)$ & 0.0 \\
\hline & $\ldots .$. & SR:B & $(0.00000)$ & 0.0 & $(0.00000)$ & 0.0 \\
\hline $\begin{array}{l}\text { Sum } \\
\text { variances }\end{array}$ & 0.04192 & & 0.00000 & $100 \%$ & 0.00000 & $100 \%$ \\
\hline $\begin{array}{l}\text { Standard } \\
\text { deviation }\end{array}$ & 0.20475 & & Relative SE: & 0.00000 & \multirow{3}{*}{\multicolumn{2}{|c|}{ Absolute SE: 0.00000}} \\
\hline Coef_G relative & & & 1.00 & & & \\
\hline Coef_G absolute & & & 1.00 & & & \\
\hline
\end{tabular}

A test is conducted to measure the reliability of the item. Reliability test performed on 16 items that have been declared valid. Using eduG-6e analysis, the reliability of the instrument is shown by Coef_G relative which is 1.00 , shown by table 5 . The process skills assessment instrument is considered to be reliable.

\section{RESULT, DISCUSSION, AND SUGGESTIONS}

The development of process skill instruments is adjusted to the construction of non-test instruments. This research follows the steps developed by Mardapi, composed by organizing instrument specifications, writing the script, reviewing instruments, testing, analysis and revisions (Mardapi, 2008). The instrument of the process skills developed is the observation sheet. Instrument process skills are used to assess students' process skills. Process skill instruments consist of grids, process skills assessment rubrics and observation sheets.

A good instrument must has three characteristics, validity, reliability and reusability (Miller, Linn \& Grondund. 2009: 70). Therefore, the validity and reliability in this study is a benchmark for quality of assessment instrument. The purpose of the assessment must be clearly and decisively formulated and determined from the start (Mardapi, 2012; Istiyono, 2014, 99). Assessment instruments are used to measure students' process skills during learning projects based on local wisdom. The appropriate way to measure the process skills is through practicum, oral presentation and observation (Feyzioğlu, Demirdağ, Akyıldız, \& Altun, 2012). The assessment instrument is in the form of assessment grids, observation sheets and assessment rubrics. The grid in the form of test questions and non-test mapping format that serves to describe the distribution and specifications of items in various topics or topics (Mardapi, 2012; Istiyono, 2014: 101). The preparation of instrument skills assessment processes is based on aspects of process skills. The 
aspects of process skills developed are translated into several indicators, namely observing, measuring, experiment, inference, predict, communications, and giving a conclusion. The indicator is translated into 16 items on the observation sheet. Each indicator has 4 assessment criteria. Instruments are said to be good if they meet the standards of validity and reliability (Miller, Linn \& Grondund. 2009: 70). In the validity test, the minimum limit of Aiken's V Index for the instrument is validity of the items, which is $\geq 0.73$ with 10 validators (R. Aiken,1985). The item is said to be reliable if the reliability value is more than 0.85 (Retnawati, 2016: 86).

Assessment in learning requires thinking about learning experiences (Asysyifa, D.S., Jumadi, Wilujeng.I. \& Kuswanto, H., 2019). One learning experience is students doing project learning. The instrument for assessing process skills can only be used in project learning. Students make gasing in groups during project learning. Gasing is one type of traditional Indonesian game. It is maked by bamboo with cilynder form. Gasing is played by turning it using a rope. The rope is wrapped around the top shaft. When the rope is pulled the top bamboo, gasing will spin quickly. The phenomenon of rotational dynamics and rigid equilibrium can be observed by students through top movements of gasing.

Based on the results of research and discussion can be concluded that the overall grain instrument assessment of the process skills of students on project-based learning local wisdom gasing is valid with a range of 0.73 to 1.00 and reliable with reliability value of 1.00 . The assessment instrument developed in the project learning was more focused on making local wisdom gasing bamboo. For further research, it is necessary to develop learning assessment instruments that are focused on other types of local wisdom.

\section{REFERENCES}

Akinbobola, A. O., \& Afolabi, F. (2010). Analysis of science process skills in west african senior secondary school certificate physics. American-Eurasian Journal of Scientific Research, 4(5), 234-240.

Ardiansyah,R., Suharno \& Triyanto. (2018). Inheritance national culture through learning in elementary school at disruptive: case study in Surakarta Indonesia. International Journal of Educational Research Review, 3(4), 48-53.

Aslan, O. (2015). How do turkish middle school science coursebooks present the science process skills?. International Journal of Environmental and Science Education, 10(6), 829-843.

Asysyifa, D.S., Jumadi, Wilujeng.I. \& Kuswanto, H. (2019). Analysis of student critical thingking skills using partial credit models (PCM) in physics learning. International Journal of Educational Research Review, $4(2), 245-253$.

Bowker, R., \& Tearle, P. (2007). Gardening as a learning environment: a study of children's perceptions and understanding of school gardens as part of an international project. Springer Science+Business Media B.V. Learning Environ Res, 83-100.

Brooks, Sara., Dobbins, Kerry., Scott, J.A., et al,. (2014). Learning about learning outcomes: the student perspective. Teaching in Higher Education, (19) 721-733.

Cardinet, Jean, Sandra Johnson, Gianreto Pini. (2010). Applying generalizability theory using eduG. New York: Routledge.

Damayanti, Indah Kurnia P. (2017). Pengembangan model outdoor learning melalui project berbasis local wisdom untuk meningkatkan keterampilan proses dan hasil belajar kognitif siswa pada materi gerak melingkar. Thesis. Yogyakarta: Pascasarjana Universitas Negeri Yogyakarta.

Ergül, N. R., \& Keskin, E. (2014). The effect of project based learning on students' science success. Procedia Social and Behavioral Sciences, (136) 537-541.

Gulay, B. (2015). Project based learning from elementary school to college, tool: architecture. Procedia - Social and Behavioral Sciences, 186, 770-775.

Mungmachon.M., R. (2012). Knowledge and local wisdom: community treasure. Internatioanl Journal of Humanities and Social Science, (13), 174-181. 
Feyzioğlu, B., Demirdağ, B., Akyıldız, M., \& Altun, E. (2012). Developing a science process skills test for secondary students: validity and reliability study. Educational Science Theory and Practice, 12(3), 18991906.s

Hadi, S. (2018). Analisis instrumen dengan eduG. Yogyakarta: Pascasarjana Universitas Negeri Yogyakarta.

Hardianti, T., \& Kuswanto, H. (2017). Difference among levels of inquiry: process skills improvement at senior high school in indonesia. International Journal of Instruction, 10(2), 119-130.

Hosnan. (2014). Pendekatan saintifik dan kontekstual dalam pembelajaran abad 21. Bogor: Ghalia Indonesia.

Istiyono, E., Mardapi, D., Suparno. (2014). Pengembangan tes kemampuan berpikir tingkat tinggi fisika (physthots) siswa SMA. Jurnal Penelitian dan Evaluasi Pendidikan, 18 (1). 1-12.

Kanhadilok, P., \& Watts, M. Western. (2013). Science and local thai wisdom: using museum toys to develop bi-gnosis. Canadian Journal of Science Mathematics and Technology Education, (13), 33-48.

Kettanun, C. (2015). Project-based learning and its validity in a thai efl classroom. Procedia - Social and Behavioral Sciences, (192) 567-573.

Suastra, I. W. \& Yasmini, L. P., B. (2013). Model pembelajaran fisika untuk mengembangkan kreativitas berpikir dan karakter bangsa berbasis kearifan lokal bali. Jurnal Pendidikan Indonesia 2 (2), 221-235.

Kulkarni, B.D., \& Tendolkar, V.D. (2015). Perception of m.phil. students regarding examination scheme blue print: a study in central india. Journal of Health Sciences Education, 2(1), 43-47.

Lasauskiene, J., \& Rauduvaite, A. (2015). Project-based learning at university: teaching experiences of lecturers. Procedia - Social and Behavioral Sciences, 197(2), 788-792.

Mardapi, Djemari. (2012). Pengukuran penilaian dan evaluasi pendidikan. Yogyakarta: Nuha Medika.

Miller, M.D., Linn, R.L., \& Gronlund, N.E., (2009). Measurement and assessment in teaching. Upper Saddle River: Pearson Educational.

Nitko, J.A., \& Brookhart, S.M. (2011). Educational assessment of students. Singapore: Pearson Merril Prentice Hall.

Okland, G. M. (2012). Determinants of learning outcome for students at high school in norway: a constructivist approach, scandinavian. Journal of Educational Research, (56), 119-138.

Osadebe, U. (2014). Teachers' assessment of classroom learning outcomes. Journal of Education and Practice, $5(15), 15-22$.

Pornpimon, C., Wallapha, A., \& Prayuth, C. (2014). Strategy challenges the local wisdom applications sustainability in schools. Procedia - Social and Behavioral Sciences, 112(Iceepsy 2013), 626-634.

R. Aiken, (1985). Three coefficients for analyzing the reliability and validty of ratings. Educational and Psychological Measurement, 131-142.

Sani, Ridwan Abdullah. (2014). Pembelajaran saintifik untuk implementasi kurikulum 2013, Jakarta: Bumi Aksara.

Saputra, D.I., Abdullah, A.G., \& Hakim, D.L. (2014). Pengembangan model evaluasi pembelajaran project based learning berbasis logika fuzzy. Jurnal INVOTEC, 10(1), 13-34.

Sheeba, M.N.,. (2013). An anatomy of science process skills in the light of the challenges to realize science instruction leading to global excellence in education. Educationia Confab, (2) 108-123.

Subali, B. (2010). Bias item test of divergen pattern of science. Jurnal Penelitian Dan Evaluasi Pendidikan, (2), 309-334

Tomoliyus, T., Sumaryanti, S., \& Jadmika, H. M. (2016). Development of validity and reliability of net game performance-based assessment on elementary students' achievement in physical education. International Journal of Assessment and Evaluation in Education, 6(6), 41-49.

Zouganeli, E., Tyssø, V., Feng, B., Arnesen, K., \& Kapetanovic, N. (2014). Project-based learning in programming classes - the effect of open project scope on student motivation and learning outcome. IFAC Proceedings, 4(7). 23-32. 